
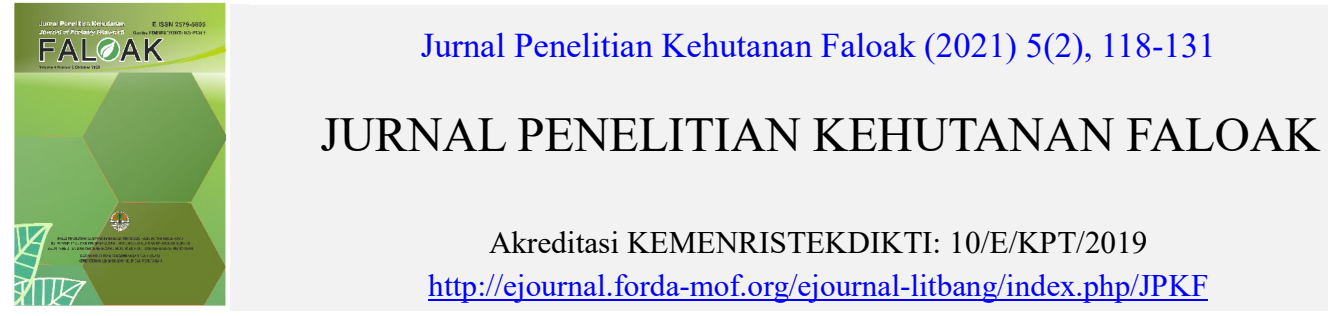

\title{
DAYA SAING MADU KELULUT LOMBOK, PROVINSI NUSA TENGGARA BARAT (The Competitiveness of Honey Kelulut Lombok, West Nusa Tenggara Province)
}

\author{
Yumantoko $^{1 *}$ dan Ramdiawan ${ }^{1}$ \\ ${ }^{1}$ Balai Penelitian dan Pengembangan Teknologi Hasil Hutan Bukan Kayu (BPPTHHBK). Alamat : Jalan Dharma Bakti \\ No 7 Desa Langko, Kecamatan Lingsar, Kabupaten Lombok Barat, Provinsi Nusa Tenggara Barat.83371
}

\begin{abstract}
Kelulut honey is one of the prioritized NTFPs in West Nusa Tenggara Province regarding its economic potential for the communities. In addition, related stakeholders have provided supports such as training, incentives, forest area management, industrialization and marketing. However, these supporst do not effectively encourage many community members to pay serious attention in cultivating kelulut bees. It can be seen from the many abandoned stup (bee box) from aid and the apathy due to the doubts about the economic potential of this business. This study aims to describe the advantages of kelulut honey cultivation in Lombok from a financial perspective. The study was conducted in two districts, West Lombok and North Lombok. Primary data was collected through interviews using a questionnaire with a purposive technique. The data was analyzed using the Policy Analysis Matrix (PAM). The results showed that kelulut honey from Lombok has competitive and comparative advantages. However, government policies remain less affected by the increasing income of bee farmers. So, efforts from stakeholders are still required to intervene in the business to attract more people in cultivating kelulut bees.
\end{abstract}

Keywords : kelulut bee, honey, competitiveness, PAM, Lombok

\begin{abstract}
ABSTRAK
Madu kelulut merupakan salah satu HHBK unggulan di Provinsi Nusa Tenggara Barat karena memberi banyak manfaat untuk masyarakat. Para pihak telah memberi intervensi antara lain dengan pelatihan, insentif modal, penataan kawasan, industrialisasi, pemasaran, dan lain sebagainya. Namun hal itu kurang mendorong masyarakat untuk mengusahakan, terlihat dari stup (kotak lebah) bantuan banyak terbengkalai dan sikap apatis karena ragu dengan potensi ekonomi madu kelulut. Penelitian ini bertujuan untuk melihat keunggulan pengusahaan madu kelulut di Lombok dilihat dari sisi finansial. Penelitian dilakukan di dua kabupaten yaitu Lombok Barat dan Lombok Utara. Data primer diperoleh lewat wawancara menggunakan kuesioner dengan teknik purposive sampling. Data selanjutnya diolah menggunakan Policy Analisis Matrix (PAM). Hasilnya menunjukkan bahwa madu kelulut dari Lombok memiliki keunggulan kompetitif dan komparatif. Namun kebijakan pemerintah belum cukup banyak memengaruhi peningkatan pendapatan petani sehingga masih diperlukan usaha dari para pihak dalam mengintervensi pengusahaan agar menarik lebih banyak lagi masyarakat dalam membudidayakan lebah kelulut.
\end{abstract}

Kata Kunci : lebah kelulut, madu, daya saing, PAM, Lombok

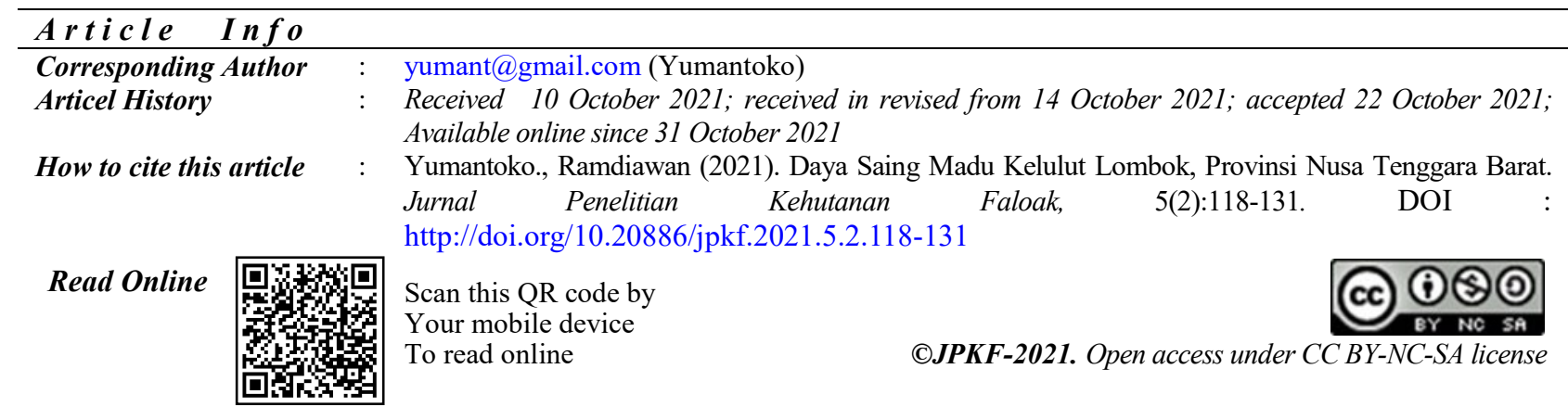




\section{PENDAHULUAN}

Madu merupakan salah satu HHBK (Hasil Hutan Bukan Kayu) unggulan Provinsi Nusa Tenggara Barat. Di Lombok, madu banyak dihasilkan dari lebah jenis kelulut (orang banyak menyebut dengan lebah trigona) yang banyak dimanfaatkan masyarakat sebagai suplemen makanan dan obat herbal. Rantai pasok madu mulai dari produsen/pemburu ke konsumen banyak memberi pendapatan pada masing-masing aktor terutama rumah tangga (Ramadhan et al., 2021) . Terkadang pelaku usaha madu kesulitan dalam memenuhi permintaan konsumen karena stok terbatas (Winahyu et al., 2021). Sementara itu, budidayanya masih perlu untuk ditingkatkan lagi kualitasnya (Budiman \& Mulyadi, 2019).

Di beberapa lokasi pengusahaan kurang berkembang karena informasi yang dibutuhkan tentang budidaya kelulut belum sampai kepada para petani, sehingga mereka mempertimbangkan usaha lain yang sudah jelas menjanjikan, misalnya usaha tanaman pertanian (Syafrizal et al., 2021). Selain itu biasanya budidaya hanya sebatas untuk konsumsi pribadi (Riendrasari et al., 2014). Kelembagaan dalam pengusahaan lebah ini belum maksimal seperti: 1) belum memiliki struktur organisasi yang mantap, lebih banyak bergerak secara informal 2) tidak memiliki manajemen yang tertata (Wahyuni et al., 2020). Terkadang, petani menghadapi kesulitan dalam mencari bahan baku usaha seperti peralatan pertukangan, kayu, dan koloni. Sehingga masih banyak ditemui pembudidaya yang kesulitan mempraktikkan cara baru yang lebih efektif dalam budidaya (Rahmayanti et al., 2018).

Para pihak telah melakukan pengembangan pengusahaan perlebahan. Intervensi yang dilakukan seperti pada
Peraturan Menteri Kehutanan No 19 Tahun 2009 Tentang Grand Strategi Pengembangan HHBK. Dalam peraturan tersebut terdapat panduan mengusahakan madu agar mencapai standar internasional. Namun kerjasama yang dominan dalam pengembangan perlebahan masih terpusat pada lembaga kehutanan terutama pemerintah, padahal potensi kerjasama dengan lembaga lain diluar itu dapat mempercepat proses pengembangan usaha perlebahan menjadi lebih baik. Dalam beberapa tahun ini di Lombok, para pihak telah memberi intervensi dengan pelatihan, insentif modal, penataan kawasan, industrialisasi, pemasaran, dan lain sebagainya antara lain dari DKPP KLU, Dinas Perindustrian Lombok Barat, BPDAS Dodokan Moyosari, Dinas LHK Provinsi NTB, BPPTHHBK, KPH Rinjani Barat, KPHL Rinjani Timur, BTN Gunung Rinjani, Bank Indonesia, Universitas Mataram, WWF, dan lainnya (Wahyuni et al., 2020). Informasi tentang cara budidaya yang baik yang disosialisaskikan banyak pihak belum bisa secara penuh memengaruhi masyarakat memperhitungkan pengusahaan madu kelulut dari sisi finansial, sehingga banyak masyarakat membudidayakannya sebagai usaha sampingan (Yumantoko \& Riendrasari, 2015).

Dengan melihat latar belakang, penelitian pengusahaan perlebahan kelulut dari sisi analisis finansial penting untuk dilakukan. Dengan mengetahui hasil analisis tersebut diharapkan pengusahaan madu kelulut bukan lagi hanya sekedar sampingan atau hobi saja namun diusahakan dengan metode pengusahaan yang tepat agar menjadi salah satu pendapatan utama bagi keluarga. 


\section{METODE PENELITIAN}

\section{A. Lokasi Penelitian}

Penelitian dilakukan pada tahun 2018 di Kabupaten Lombok Barat, dan Kabupaten Lombok Utara. Pemilihan lokasi adalah berdasarkan hasil penelitian Riendrasari et al., (2014) yang menyebut bahwa pengusahaan lebah kelulut sudah marak di dua kabupaten tersebut. Di Kabupaten Lombok Utara pengambilan sampel di Kecamatan Tanjung, dan Kecamatan Gangga, sedangkan di Kabupaten Lombok Barat pengambilan sampel di Kecamatan Lingsar, dan Kecamatan Batulayar. Kecamatan tersebut memiliki petani yang mengusahakan lebah kelulut baik sendiri maupun berkelompok dan populasi stupnya termasuk banyak.

\section{B. Metode Pengambilan Sampel}

Pemilihan sampel dilakukan menggunakan metode purposive dengan kriteria petani yang berada di Lombok Barat dan Lombok Utara. Setiap kabupaten dipilih dua lokasi yang pengusahaan kelulutnya dominan. Responden yang dipilih merupakan petani yang memiliki pengalaman budidaya lebih dari satu tahun dan usaha masih berjalan. Data yang dikumpulkan berupa daftar harga input dan output usaha dari masing-masing unit usaha yang dilakukan oleh responden.

\section{Analisis data}

Penelitian ini menggunakan Analisis Matriks Kebijakan (Policy Analysis Matrix/PAM). PAM digunakan untuk : analisis kelayakan baik secara privat maupun secara sosial, serta dampak intervensi atau kebijakan pemerintah terhadap sistem komoditas. Analisis daya saing membutuhkan data pokok dan proses sebagai berikut; (a) data input-output fisik usaha tani komoditas yang diteliti; (b) Harga finansial dan ekonomi input-output fisik usaha tani; (c) pemisahan komponen domestik dan asing masukan (input ) usaha tani; (d) penghitungan indikator hasil analisis keuntungan, efisiensi finansial dan ekonomi, dan dampak kebijkan pemerintah (Rusastra et al., 2004). Gambaran PAM dapat dilihat pada Tabel 1.

Tabel 1. Policy Analysis Matrix (PAM)

Table 1. Policy Analysis Matrix

\begin{tabular}{|c|c|c|c|c|}
\hline & \multirow[b]{2}{*}{$\begin{array}{l}\text { Penerimaan } \\
\text { (Revenue) }\end{array}$} & \multicolumn{2}{|c|}{ Biaya (Cost) } & \multirow[b]{2}{*}{$\begin{array}{c}\text { Keuntungan } \\
\text { (Profit) }\end{array}$} \\
\hline & & $\begin{array}{l}\text { Input tradable } \\
\text { (Tradable Input) }\end{array}$ & $\begin{array}{l}\text { Faktor Internal } \\
\text { (Internal Factor) }\end{array}$ & \\
\hline Harga privat & A & B & $\mathrm{C}$ & $\mathrm{D}=\mathrm{A}-\mathrm{B}-\mathrm{C}$ \\
\hline Harga sosial & $\mathrm{E}$ & $\mathrm{F}$ & G & $\mathrm{H}=\mathrm{E}-\mathrm{F}-\mathrm{G}$ \\
\hline Divergensi & $\mathrm{I}=\mathrm{A}-\mathrm{E}$ & $\mathrm{J}=\mathrm{B}-\mathrm{F}$ & $\mathrm{K}=\mathrm{C}-\mathrm{G}$ & $\mathrm{L}=\mathrm{I}-\mathrm{J}-\mathrm{K}=\mathrm{D}-\mathrm{H}$ \\
\hline $\begin{array}{l}\text { Sumber } \text { (sourc } \\
\text { Keterangan }(\text { Ren } \\
\mathrm{A}=\text { Penerimaan } \\
\mathrm{B}=\text { Biaya Input } \\
\mathrm{C}=\text { Biaya Input } \\
\mathrm{D}=\text { Keuntungan } \\
\mathrm{E}=\text { Penerimaan } \\
\mathrm{F}=\text { Biaya Input }\end{array}$ & $\begin{array}{l}\text { Monke \& Pearsor } \\
\text { rks): } \\
\text { ivat } \\
\text { adable Privat } \\
\text { on Tradable Privat } \\
\text { rivat } \\
\text { sial } \\
\text { adable }\end{array}$ & ( 1989), dan Pearson, & $\begin{array}{l}\text { 1, \& Bahri, (2005) } \\
\text { Biaya Input Non Tradab } \\
\text { Keuntungan Sosial } \\
\text { ransfer Output } \\
\text { ransfer Input Tradable } \\
\text { Transfer Faktor } \\
\text { Transfer Bersih }\end{array}$ & \\
\hline
\end{tabular}


Untuk menganalisis daya saing dapat dijabarkan berdasar analisis keuntungan, efisiensi finansial, dan dampak kebijakan pemerintah adalah sebagai berikut : (Zakaria et al., 2010)

1. Analisis Keuntungan

a. Private Profitability/Keuntungan Privat $(\mathrm{PP}), \quad \mathrm{D}=\mathrm{A}-(\mathrm{B}+\mathrm{C})$, merupakan indikator daya saing dari sistem komoditas berdasarkan teknologi, nilai output, biaya input, dan transfer kebijakan.

Keuntungan privat dihitung menggunakan harga aktual di lapangan. Data yang digunakan berasal dari petani. Perhitungan ini untuk mencari keuntungan dengan cara menghitung seluruh keuntungan yang kemudian dikurangi beban usaha. Untuk menghitung baik keuntungan privat dan sosial, penelitian ini mencari perhitungan untuk satu stup. Kemudian agar dapat menggambarkan dari suatu unit usaha maka dikali dengan seratus atau menghitung untuk seratus stup. Pada lampiran 1 disajikan komponen perhitungan keuntungan privat yang digunakan.

b. Social Profitability/Keuntungan Sosial (SP), $\mathrm{H}=\mathrm{E}-(\mathrm{F}+\mathrm{G})$, merupakan indikator keuntungan komparatif dari sistem komoditas pada kondisi tidak ada divergensi harga akibat kebijakan. Perhitungan ini menggunakan gabungan antara harga riil di lapangan dengan harga yang tidak sebenarnya atau harga bayangan. Pada lampiran 2 disajikan komponen perhitungan keuntungan sosial.

2. Efisiensi Finansial (Keunggulan kompetitif) dan Efisiensi Ekonomi (Keunggulan Komparatif)

a. Private Cost Ratio $(\mathrm{PCR})=\mathrm{C} /(\mathrm{A}-\mathrm{B})$, yaitu indikator yang menunjukan kemampuan sistem usaha untuk membayar biaya domestik dan tetap kompetitif b. Domestic Resources Cost Ratio (DRCR) = $\mathrm{G} /(\mathrm{E}-\mathrm{F})$, yaitu indikator yang menunjukan jumlah sumber daya domestik yang dapat dihemat untuk menghasilkan satu unit devisa system mempunyai keunggulan komparatif.

3. Dampak Kebijakan Pemerintah

a. Kebijakan output

(1) Output Transfer (OT) = A-E, jika nilai OT $>0$ menunjukan adanya transfer dari masyarakat atau pemerintah terhadap produsen, demikian juga sebaliknya

(2) Nominal Protection Coefficient on Output $(\mathrm{NPCO})=$ A/E. kebijakan bersifat protektif terhadap output, jika nilai $\mathrm{NPCO}>1$. Semakin besar nilai NPCO, berarti semakin tinggi tingkat protektif pemerintah terhadap output.

b. Kebijakan Input-Output

(1) Effective Protection Coefficient (EPC) $=(\mathrm{A}-\mathrm{B}) /(\mathrm{E}-\mathrm{F})$, yaitu indikator yang menunjukan tingkat proteksi simultan terhadap output dan input tradable. Kebijakan masih bersifat protektif jika EPC $>1$. Semakin besar nilai EPC, berarti semakin tinggi tingkat proteksi pemerintah terhadap komoditas pertanian domestik.

(2) Profitability Coefficient $(\mathrm{PC})=\mathrm{D} / \mathrm{H}$; jika $\mathrm{PC}=0$ berarti secara keseluruhan kebijakan pemerintah memberikan insentif kepada produsen.

(3) Subsidy Ratio to Producer (SRP) = (D-H)/E. Indikator yang menunjukan proporsi penerimaan pada harga sosial yang diperlukan apabila subsisdi digunakan sebagai pengganti kebijakan 


\section{HASIL DAN PEMBAHASAN}

\section{A. Karakteristik Responden}

Tabel 2 menyajikan informasi karakteristik responden di lokasi penelitian. Penelitian ini mengumpulkan data 60 responden yang tersebar di Lombok utara sebanyak 30 orang dan Lombok Barat sebanyak 30 orang. Rata-rata umur petani lebah di kedua lokasi tidak jauh berbeda dimana di Lombok Barat 44, 4 tahun, dan Lombok Utara 40,5 tahun. Tingkat pendidikan di kedua lokasi yaitu di Lombok Barat sebanyak 3 persen responden tidak sekolah, di
Lombok Utara yaitu 7 persen tidak sekolah. Sebagian besar mereka yang membudidayakan lebah bekerja sebagai petani yaitu 77 persen di Lombok Barat, dan 60 persen di Lombok Utara. Di Lombok Utara 60 persen responden menjadi anggota kelompok tani, di Lombok Utara jumlahnya lebih besar lagi yaitu 87 persen. rata-rata lama usaha tidak terlalu berbeda, di Lombok Barat rata-rata sudah berjalan 4,6 tahun, dan 4,9 tahun di Lombok Utara. Kepemilikan stup di Lombok Barat rata-rata 72,6 buah, dan 101,9 buah stup di Lombok Utara.

Tabel 2. Karakteristik Responden

Table 2. Characteristics of Respondents

\begin{tabular}{|c|c|c|c|}
\hline No $(N o)$ & Kriteria (Criteria) & Lombok Barat & Lombok Utara \\
\hline 1 & Jumlah Responden & 30 & 30 \\
\hline 2 & Rata-rata umur & 44,4 Tahun & 40,5 \\
\hline \multirow[t]{6}{*}{3} & Pendidikan & Tidak sekolah : 3\% & Tidak sekolah : $7 \%$ \\
\hline & & SD $\quad: 53 \%$ & $\mathrm{SD} \quad: 40 \%$ \\
\hline & & SMP : $10 \%$ & SMP : $7 \%$ \\
\hline & & SMA : $27 \%$ & SMA : $30 \%$ \\
\hline & & $\mathrm{S} 1 \quad: 7 \%$ & $: 3 \%$ \\
\hline & & & $: 13 \%$ \\
\hline \multirow[t]{3}{*}{4} & Pekerjaan & Petani : $77 \%$ & Petani : $60 \%$ \\
\hline & & Lain-lain : $23 \%$ & Guru : $7 \%$ \\
\hline & & & Lain-lain : \\
\hline \multirow[t]{2}{*}{5} & Anggota kelompok tani/Non anggota & Anggota : $60 \%$ & Anggota : $87 \%$ \\
\hline & & Non anggota : $40 \%$ & Non anggota : $13 \%$ \\
\hline 6 & Rata-rata lama usaha perlebahan & 4,6 tahun & 4,9 tahun \\
\hline 7 & $\begin{array}{l}\text { Rata-rata kepemilikan stup per } \\
\text { responden }\end{array}$ & 72,6 buah & 101,9 buah \\
\hline
\end{tabular}

\section{B. Perhitungan Policy Analysis Matrix (PAM)}

Hasil penghitungan PAM disajikan pada Tabel 3 dengan menggunakan satuan analisis per satu stup. Hasil perhitungan dikali seratus atau perhitungannya menjadi seratus stup agar dapat menggambarkan skala usaha di masyarakat. 
Tabel 3. Perhitungan PAM untuk 100 buah stup

Table 3. PAM calculation for 100 stups

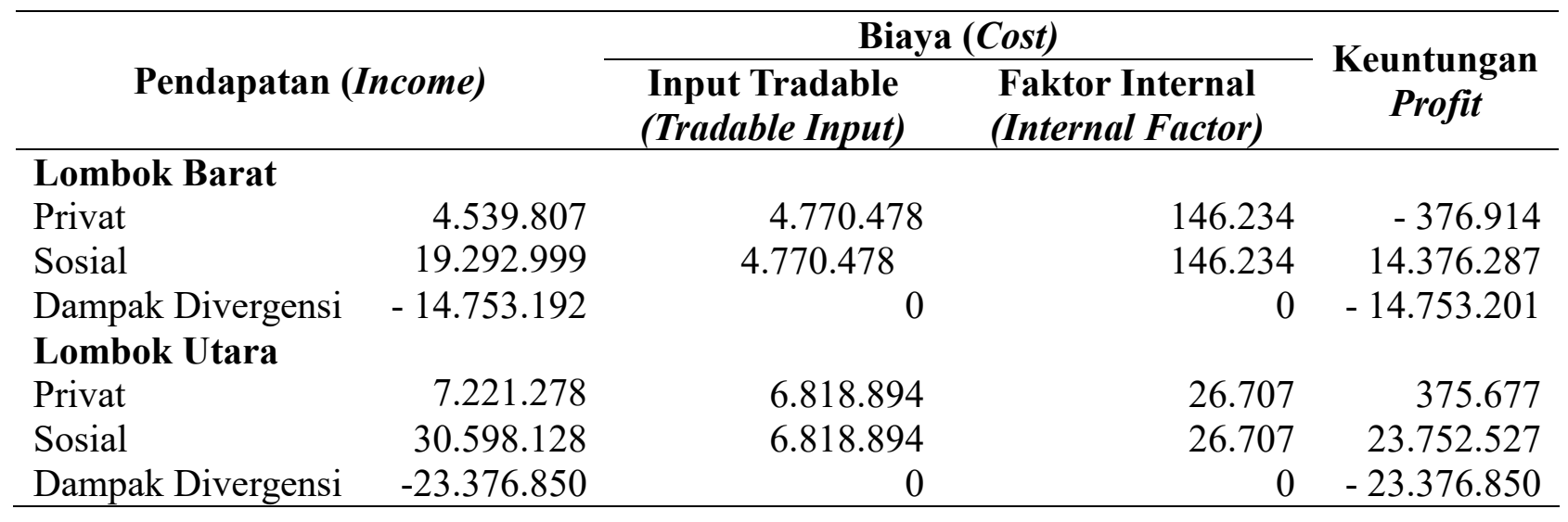

Asumsi yang digunakan dalam perhitungan adalah, pertama harga privat adalah harga aktual yang dikeluarkan oleh petani tanpa menambahkan harga bayangan baik untuk analisis input maupun analisis output. Kedua, dalam menentukan faktor pengganti dari faktor produksi tanah untuk kegiatan usaha yang lain dianggap nol karena berdasarkan kondisi dilapangan, para petani banyak yang menggunakan tembok untuk menggantung stup sehingga opportunity cost lahannya tidak dihitung. Sedangkan untuk menentukan keuntungan sosial, penelitian ini menggunakan asumsi harga bayangan. Harga bayangan sangat berguna ketika peneliti kesulitan menentukan nilai yang tepat dari harga sesungguhnya. Alasan penggunaan harga bayangan adalah pertama, harga ini tidak mencerminkan biaya lain jika sumberdaya tersebut digunakan untuk hal lain. Kedua, harga yang didapat masyarakat tidak mencerminkan nilai dari barang yang didapat (Gittinger, 1972). Perhitungan untuk input tradable dan faktor internal dapat menggunakan harga yang mendekati atau sama harga privat karena distorsi pasar baik lahan, tenaga kerja maupun biaya modal kurang bisa terlihat (Sukmaya et al., 2016; Monke \& Pearson, 1989 ), untuk itu biaya sosial dihitung sama dengan biaya privat sehingga dampak divergensinya menjadi 0 .

Berdasarkan hasil perhitungan, diperoleh bahwa madu kelulut dari Lombok memiliki daya saing dengan madu luar negeri terutama Malaysia. Penelitian ini menggunakan harga bayangan Malaysia dengan satuan kilo. Harga satu kilo madu kelulut di Malaysia pada saat dilakukan penelitian yaitu 200-400 Ringgit (Abdurofi, 2018). Perlu diketahui bahwa Malaysia merupakan salah satu eksportir madu terbesar di kawasan ASEAN terutama untuk tujuan Eropa (Tempo.com, 2015). Sementara itu ekspor madu Indonesia pada periode yang sama (2004-2018) mengalami trend penurunan (Ariyanto et al., 2021).

Keuntungan privat di Lombok Barat untuk tahun pertama negatif (- Rp 376.914). Hal ini disebabkan karena tergerus dengan biaya memulai usaha seperti pembelian bahan baku modal. Untuk tahun berikutnya diasumsikan beban usaha untuk modal sudah tidak ada. Di Kabupaten Lombok Utara sejak tahun pertama memperoleh untung sebesar Rp 375.677. Hal ini bisa jadi karena produksi madu di Kabupaten Lombok Utara secara keseluruhan lebih banyak dari Lombok Barat.

Biaya produksi di Lombok Utara lebih besar dari Lombok Barat, hal ini dikarenakan 
petani di Lombok Utara lebih memilih menggunakan bahan yang bagus kualitasnya. Misalnya untuk membuat stup, kandang, peralatan panen, dan lain sebagainya. Dengan menggunakan berbagai bahan dan peralatan yang bagus mampu mendukung kelancaran usaha, namun biaya juga ikut besar. Sedangkan di Lombok Barat masih ada pembudidaya yang belum memperhatikan kualitas misalnya masih ada pembudidaya yang belum memindahkan koloni ke stup, atau dengan kata lain koloni masih di tempat aslinya misalnya bambu.

Hasil penghitungan memperlihatkan bahwa Lombok Utara memiliki keuntungan sosial yang lebih besar dari Lombok Barat, hal ini dipengaruhi oleh produksi madu disana lebih tinggi. Baik Lombok Utara maupun Lombok Barat sama-sama memiliki keuntungan sosial yang positif. Hal ini berarti bahwa kedua daerah tersebut memiliki keunggulan komparatif dalam pengembangan madu kelulut.

Dampak kebijakan terhadap usaha lebah kelulut dianalisis berdasarkan tujuh rasio yang disajikan pada Tabel 4.

Tabel 4. Indikasi Kebijakan Pada Sistem Usaha Tani Madu

Table 4. Policy Indications in the Honey Farming System

\begin{tabular}{clrc}
\hline No (No) & \multicolumn{1}{c}{ Rasio (Ratio) } & Lombok Barat & Lombok Utara \\
\hline 1 & NPCO (Nominal ProtectionCoefficient of Output) & 0,235 & 0,236 \\
2 & NPCI (Nominal Protection Coefficient of Input) & 1 & 1 \\
3 & PCR (Private Cost Ratio) & $-0,633$ & 0,004 \\
4 & DRCR (Domestic Resource Cost Coeficient) & 0,01 & 0,001 \\
5 & EPC (Effective Protection Coeficient) & 0,0158 & 0,0169 \\
6 & PC (Profiitiability Coefficient) & $-0,0262$ & 0,0158 \\
7 & SRP (Sudsidy Ratio to Producer) & $-0,764$ & $-0,763$ \\
\hline
\end{tabular}

Nilai NPCO adalah koefisien proteksi output nominal yang diperoleh dari penerimaan privat dibagi dengan perolehan sosialnya. Kebijakan dikatakan protektif jika NPCO $>1$, dan $\mathrm{NPCO}<1$ menunjukan bahwa tidak ada protektif dari pemerintah. Dalam Tabel 4 menunjukan bahwa nilai NPCO baik di Lombok Utara dan Lombok Barat memiliki perbedaan yang sangat kecil yakni 0,235 dan 0,236 yang berarti bahwa dimana petani menerima harga aktual yang lebih rendah dari harga seharusnya.
Nilai NPCI baik Lombok Utara dan Lombok Barat menunjukan angka yang sama "1". Hal ini menunjukan bahwa harga input tradable di kedua lokasi tersebut sama dengan harga di tingkat nasional.

Nilai PCR kurang dari 1 yang artinya adalah , usaha ini memiliki keunggulan kompetitif dan menguntungkan. Sedangkan PCR $>1$ berarti usaha tidak memiliki keuntungan. Nilai PCR menunjukan besaran sistem komoditi dalam membiayai input non tradable pada level privat. Berdasarkan Tabel 4, 
usaha budidaya lebah kelulut yang baik yang berada di Lombok Utara maupun Lombok Barat memiliki nilai dibawah 1, ini artinya adalah komoditas madu kelulut yang berasal dari dua daerah tersebut memiliki keunggulan kompetitif.

Nilai DRCR $>1$ memiliki arti usaha yang dijalankan tidak memiliki keunggulan komparatif. Nilai DRCR $<1$ menunjukan bahwa usaha budidaya lebah kelulut memiliki keungguan komparatif. Usaha ini dapat berjalan tanpa adanya intervensi pemerintah. Dari Tabel 4 menunjukan bahwa usaha budidaya lebah kelulut yang dilakukan baik di Lombok Utara dan Lombok Barat memiliki keunggulan komparatif karena lebih murah dari harga madu di tingkat internasional.

Nilai EPC $>1$ memperlihatkan bahwa pemerintah meningkatkan harga output atau input tradabel diatas harga sosial. Dan apabila nilai EPC $<1$ menunjukan bahwa kebijakan yang diterapkan tidak berjalan efektif. Dari Tabel 4 menunjukan bahwa baik di Kabupaten Lombok Utara maupun Lombok Barat memiliki nilai EPC dibawah angka 0 yang ini berarti bahwa kebijakan yang diterapkan tidak berjalan efektif.

Nilai PC digunakan untuk meng hitung dampak seluruh transfer atas keuntungan privat dan sosial. Nilai PC $<1$ berarti pemerintah memberikan insentif kepada produsen, sedangkan PC $>1$ menunjukan bahwa kebijakan pemerintah membuat pendapatan produsen lebih kecil jika tidak ada kebijakan. Berdasar Tabel 4 menunjukan bahwa baik di Lombok barat maupun Lombok Utara memiliki nilai yang berada dibawah angkat 1 yang menunjukan bahwa pemerintah memberikan insentif kepada pengusaha.

Nilai SRP bernilai positif maka intervensi pemerintah mampu meningkatkan keuntungan, sebaliknya apabila negatif berarti intervensi pemerintah tidak bisa meningkatkan keuntungan. Berdasar perhitungan, SRP bernilai negative baik di Lombok Utara dan Lombok Barat. Ini artinya adalah kebijakan selama ini belum mampu meningkatkan keuntungan petani. Diperlukan usaha yang lebih besar lagi agar intervensi pemerintah mampu merubah pendapatan. Misalnya pemberian bantuan modal untuk pembuatan stup dan kandang lebah.

\section{Upaya Meningkatan Daya Saing}

Keunggulan kompetitif dan komparatif adalah keunggulan yang sengaja diciptakan dengan cara memeroleh hasil terbaik dengan biaya seefisien mungkin. Ada beberapa cara yang dapat dilakukan untuk meningkatkan daya saing. Berdasarkan perhitungan pada tabel 4 untuk meningkatkan daya saing (agar nilai PCR $<1$ ), yaitu mengurangi beban usaha dan menaikan keuntungan, misalnya dengan memberi insentif kepada petani yang akan memulai usaha seperti bantuan peralatan dan modal pinjaman dengan bunga rendah. Peningkatan keuntungan dapat diperoleh dengan cara memperbanyak produksi madu dengan penggunaan cara-cara tepat dalam produksi misalnya dengan pemilihan koloni lebah yang berkualitas, perawatan stup secara rutin, dan pemanenan yang memerhatikan kelestarian lebah. Sementara itu, $\mathrm{Su}$ et al. (2020) melihat bahwa untuk meningkatkan daya saing produk kehutanan adalah dengan membuat nilai tambah. Salah satu permasalahan selama ini adalah kurangnya inovasi dalam pemasaran dan hal ini dapat menurunkan penjualan ( Evelin et al., 2021). Sebagian besar produk perlebahan di Lombok dijual dalam bentuk madu. Polen dan propolis belum dimanfaatkan secara baik. Penciptaan nilai tambah dengan berbagai macam produk olahan selain madu seperti dari hasil propolis, dan polen diharapkan akan menambah 
pendapatan petani (Pribadi et al., 2020). Selain itu lebah kelulut memiliki potensi sebagai atraksi wisata yang menarik (Febriani \& Saputra, 2018)

Menurut Porter (1987) daya saing dapat ditingkatkan dengan empat hal: kondisi faktor (factor condition), kondisi permintaan (demand condition), industri terkait dan industri pendukung yang kompetitif (related and supporting industry), dan kondisi terstruktur, persaingan dan strategi industry (firm strategy, structure, and rivalry). Untuk faktor kondisi yang berkaitan dengan sumber daya alam di Lombok Utara dan Lombok Barat sudah mendukung misalnya ketersedian pakan yang mencukupi di tempat tertentu yang vegetasi tanamannya menghasilkan pakan lebah dalam jumlah banyak. Para pihak telah mengintervensi diantaranya dengan penanaman tanaman yang disukai lebah. Untuk demand atau permintaan madu diperkirakan untuk beberapa tahun kedepan akan tinggi ( Pratama, Fauzi, \& Sukardi, 2020). Industri pendukung yang berkaitan dengan produksi dan pasca produksi madu masih terbuka dan berkembang (Kamila et al., 2017). Industrialisasi mulai dari hulu hingga hilir perlu didorong sehingga nantinya hal ini dapat menekan biaya produksi menjadi rendah dan produk perlebahan yang dihasilkan lebih bervariasi. Di Karang Bayan, Lombok Barat misalnya sudah ada usaha pembuatan minuman polen sebagai bagian dari diversifikasi produk lebah kelulut. Untuk kondisi terstruktur, persaingan dan strategi industri memperlihatkan bahwa usaha yang dilakukan pembudidaya dilakukan tanpa adanya persaingan untuk mencari pasar. Selain dipasarkan secara pribadi oleh anggota, biasanya kelompok tani juga terlibat dalam pemasaran madu bersama-sama anggota. Namun jaringannya kurang luas karena sebagian besar untuk pasar di Lombok. Agar pasar lebih terbuka, kelompok tani dapat bermitra dengan pihak lain misalnya industri yang membutuhkan bahan baku madu seperti farmasi dan makanan, sehingga kepastian pasar menjadi lebih terjamin dan luas.

\section{KESIMPULAN}

Berdasarkan hasil analisis PAM menunjukan bahwa usaha budidaya lebah kelulut di Lombok memiliki daya saing. Secara umum Lombok Utara memiliki keunggulan lebih baik dari Lombok Barat dalam hal produktivitas. Intervensi yang dapat dilakukan untuk membuat daya saing adalah dengan meningkatan produksi dan menekan biaya produksi. Peningkatan produksi dapat dilakukan mulai dari pemilihan koloni yang berkualitas, perawatan stup, dan panen yang memerhatikan kelestarian lebah. Selain itu perlu diupayakan diversifikasi produk perlebahan agar tidak tergantung dengan hasil dari madu saja, misalnya petani dapat memanfaatkan potensi polen dan propolis. Biaya input dapat ditekan dengan pemberian insentif kepada petani yang akan memulai usaha seperti bantuan peralatan dan modal pinjaman dengan bunga rendah yang dapat disalurkan oleh berbagai lembaga keuangan dengan syarat yang mudah.

Penelitian ini menghitung biaya sosial sama dengan harga privat karena menganggap tidak ada gangguan pasar sehingga penelitian kedepan perlu untuk melakukan penghitungan biaya sosial karena adanya distorsi pasar.

\section{UCAPAN TERIMAKASIH}

Penulis mengucapkan terimakasih kepada para pihak yang telah membantu dalam penelitian ini terutama Balai Penelitian dan Pengembangan Teknologi Hasil Hutan Bukan Kayu yang telah mendanai penelitian. 


\section{KONTRIBUSI PENULIS}

Yumantoko sebagai kontributor utama dan Ramdiawan sebagai kontributor anggota.

\section{DAFTAR PUSTAKA}

Abdurofi, I. (2018). Financial and Economic Analyses of Stingless Bee Farming in Malaysia. University Putra Malaysia.

Ariyanto, Y. A., Darwanto, D. H., \& Utami, A. W. (2021). Daya Saing Madu Indonesia dI ASEAN. Diambil dari Universitas Gadjah Mada http://etd.repository.ugm.ac.id/penelitia n/detail/196928

Budiman, I., \& Mulyadi. (2019). Peningkatan Kualitas Mutu Madu Kelulut (Trigona Sp.) Menggunakan Mesin Venturi Dan Dehumidifier Untuk Meningkatkan Ekonomi Masyarakat Di Desa Madurejo, Kecamatan Pengaron, Kabupaten Banjar. Prosiding Seminar Nasional Pengabdian kepada Masyarakat (pp. 61-66). Lembaga Penelitian dan Pengabdian kepada Masyarakat, Universitas Lambung Mangkurat.

Febriani, L., \& Saputra, P. P. (2018). Modal Sosial Dalam Pengembangan Madu Kelulut Sebagai Komoditas Ekonomi Dan Pariwisata Di Kecamatan Lubuk Kabupaten Bangka Tengah. Society, 83-91.

Gittinger, J. P. (1972). Economic Analysis of Agricultural Projects. Maryland: Johns Hopkins University Press.

Kamila, R., Syarief, R., \& Saptono, I. T. (2017). Analisis Pengembangan Bisnis Madu Pada Cv Ath-Thoifah Dengan Pendekatan Business Model Canvas. Jurnal Agribisnis Indonesia, 173-184.
Master, W. A., \& Winter-Nelson, A. (31 Januari 2016). Measuring the Comparative Advantage of Agricultural Activities: Domestic Resources Cost and the Social Cost-Benefit Ratio. Diambil dari http://sites.tufts.edu/willmasters/files/20 10/06/Masters-WinterNelson_DRCs_A JAE1995.pdf

Monke, E. A., \& Pearson, S. R. (1989). The Policy Analysis Matrix For Agricultural Development. Ithaca and Loncon: Cornell University Press.

Pearson, S., Gotsch, C., \& Bahri, S. (2005). Aplikasi Policy Analysis Matrix pada Pertanian Indonesia. Jakarta: Yayasan Obor Indonesia.

Porter, M. E. (1987). Strategi bersaing: teknik menganalisis industri dan pesaing. Jakarta: Erlangga.

Pratama, A. S., Fauzi, M. A., \& Sukardi. (2020). Strategi Peningkatan Daya Saing Produk Madu (Studi Kasus: Pt Madu Pramuka). Jurnal Aplikasi Manajemen dan Bisnis, , 178-187.

Pribadi, A., Yunianto, A. S., Hajjah, N., \& Sarah, F. A. (2020). Pemberdayaandan usaha peningkatan ekonomi suku Talang Mamak di kawasan Taman Nasional Bukit Tiga Puluh melalui budidaya Kelulut (Heterotrigonaitama). Seminar Nasional Pemberdayaan Masyarakat (pp. 98-105). Pekanbaru: Universitas Riau.

Ramadhan, I. H., Abidin, Z., Fauzi, H., Satriadi, T., \& Itta, D. (2021). Kelayakan Dan Kontribusi Usaha Lebah Madu Kelulut Di Desa Telaga Langsat Kabupaten Tanah Laut. Jurnal Hutan Tropis, 397-404. 
Rahmayanti, S. A., Yusuf, M., \& Husni, S. (2018). Kontribusi Usaha Budidaya Lebah Madu (Trigona Sp) Terhadap Pendapatanrumah Tangga Petani Di Kecamatan Bayan Kabupaten Lombok Utara. Agroteksos, 73-80.

Riendrasari, S. D., Yumantoko, \& Kurniawan, E. (2014). Analisis Kelayakan Usaha Budidaya Lebah Madu Trigona spp di Provinsi Nusa Tenggara Barat. Mataram: Balai Penelitian Teknologi Hasil Hutan Bukan Kayu.

Rouf, A. A., A, D., \& A, F. (2014). Daya Saing Usaha Sapi Potong di Indonesia : Pendekatan Domestic Resources Cost. Wartazoa, 97-107.

Rusastra, I. W., Rachman, B., \& Friyatno, S. (2004). Analisis Daya Saing dan Struktur Proteksi Komoditas Palawija. Dalam Prosising: Efisiensi dan Daya Saing Sistem Usahatani Beberapa Komoditas Pertanian di Lahan Sawah. Pusat Penelitian dan Pengembangan Sosial Ekonomi Pertanian, 28-48.

Su, H., Hou, F., Yang, Y., Han, Z., \& Liu, C. (2020). An Assessment of the International Competitiveness of China's Forest Products Industry. Forest Policy and Economics.

Sukmaya, S. G., Rachmina, D., \& Saptana . (2016 ). Analisis Daya Saing Dan Dampak Kebijakan Pemerintah Terhadap Komoditas Kedelai Vs Pengusahaan Kedelai Di Kabupaten Lamongan, Jawa Timur. Forum Agribisnis, 21-52.

Syafrizal, Kusuma, I. W., Saud, O. R., Wiandany, R., Yahya, M. F., \& Harmonis. (2021). Conservation of kelulut (stingless bee) in East and North
Kalimantan, Indonesia. The 7th Symposium of JAPAN-ASEAN Science Technology Innovation Platform (JASTIP) (hal. 1-6). IOP Publishing.

Tempo.com. (2 Oktober 2015). Ekspor Madu, Indonesia Kalah Bersaing dengan Malaysia. Diambil dari Tempo: https://bisnis.tempo.co/read/705901/eks por-madu-indonesia-kalah-bersaing-den gan-malaysia/full\&view $=$ ok

Velin , O., Prima, F., \& Sujana, I. (2021). Strategi Pemasaran Madu Kelulut Dalam Rangka Mendukung Produk Unggulan Khas Kalimantan Barat Menggunakan Analisis SWOT DAN QSPM. Jurnal Teknik Industri UNTAN, 45-52.

Wahyuni, N., Riendrasari, S. D., Hasan, R. A., Hidayatullah, M., Handoko, C., Anggadhania, L., \& Yumantoko. (2020). Produk Perlebahan NTB. Yogyakarta dan Makassar: Nas Media.

Wiendiyati, Raya , U. R., \& Un , P. (2002). Semantic Scholar. Diambil dari https://pdfs.semanticscholar.org/332e/e 052f38f4b4075ba61f489985bfaef2b44f 8.pdf?_ga=2.80726878.818810139.153 1961317-468512975.1531961317

Winahyu, N., Amirudin, F., \& Azizah, I. N. (2021). Analisis Pemasaran Lebah Madu Klanceng (Trigona sp.) di Kecamatan Pagerwojo Kabupaten Tulungagung pada Masa Pandemi Covid-19. Jurnal Agribest, 25-33.

Yumantoko, \& Riendrasari, S. D. (2015). Kajian Pengusahaan Lebah Trigona Sp Di Lombok Utara. Seminar Nasional Sewindu Balai Penelitian Teknologi Hasil Hutan Bukan Kayu (hal. 530-538). Mataram: BPPTHHBK. 
Zakaria, A. K., Sejati, W. K., \& Kustiari, R. (2010). Analisis Daya Saing Komoditas Kedelai Menurut Agro Ekosistem:
Kasus Tiga Provinsi di Indonesia. Jurnal Agro Ekonomi, 21-37. 
Lampiran 1. Komponen perhitungan kentungan privat Apendix 1. Components of private profitability calculation

\begin{tabular}{lrr}
\hline $\begin{array}{c}\text { Komponen } \\
\text { (Component) }\end{array}$ & Lombok Barat & Lombok Utara \\
\hline Input & $\mathbf{4 . 7 7 0 . 4 7 8}$ & $\mathbf{6 . 8 1 8 . 8 9 4}$ \\
Kandang & 1.786 .042 & 1.182 .776 \\
Benih & 1.877 .181 & 2.730 .741 \\
Stup & 896.924 & 1.752 .725 \\
Koloni+stup & 153.811 & 1.024 .709 \\
Bunga & 4.362 & 44.368 \\
Peralatan & 51.240 & 83.575 \\
Lainnya & 918 & - \\
Tenaga Kerja & $\mathbf{1 4 6 . 2 3 4}$ & $\mathbf{2 6 . 7 0 7}$ \\
Pembuatan Kandang & 90.220 & 12.718 \\
Pembuatan stup & 46.832 & 12.899 \\
Panen & - & 1.090 \\
Perawatan & 4.591 & - \\
Pemindahan koloni & 4.591 & - \\
Lainnya & - & - \\
Sewa & - & - \\
Transportasi & - & \\
Output & & 7221278,168 \\
Harga output & 4.539 .807 & \\
\hline
\end{tabular}


Lampiran 2. Komponen perhitungan kentungan privat Apendix 2. Components of private profitability calculation

\begin{tabular}{lr}
\hline \multicolumn{1}{c}{$\begin{array}{c}\text { Tahap Penghitungan } \\
\text { (Calculation steps) }\end{array}$} & $\begin{array}{r}\text { Madu } \\
\text { (Honey) }\end{array}$ \\
\hline 1. F.o.b Malaysia (\$/ton) & 40.000 \\
2. Pengiriman (\$/ton) (International Surface Parcel Pos Malaysia) & 354,36 \\
3. C.i.f. Mataram & 4354,36 \\
4. Nilai tukar (Rp/\$) & 14.000 \\
5. Nilai tukar keseimbangan & 14.000 \\
6. C.i.f dalam mata uang domestic & 620.961 \\
7. Faktor konversi berat (kg/ton) & 1000 \\
8. C.i.f dalam mata uang domestic (Rp/kg) & 620.961 \\
9. Transportasi (Rp/kg) & 16.500 \\
10. Harga paritas import ditingkat petani $(\mathrm{Rp} / \mathrm{kg})$ & 637.461 \\
\hline
\end{tabular}

